\title{
STATUS OF POPULATIONS OF THE WHITE-TAILED PTARMIGAN AT THE SOUTHERN EDGE OF ITS RANGE
}

\author{
Donald H. Wolfe ${ }^{1}$, Lena C. LaRsson ${ }^{1}$, Jerry R. Oldenettel ${ }^{2}$, \\ hira A. Walker ${ }^{3}$, and Michael A. Patten ${ }^{4}$
}

${ }^{1}$ Sutton Avian Research Center, University of Oklahoma, P.O. Box 2007, Bartlesville, OK 74005, USA.E-mail: dwolfe@ou.edu

2499 Farm-to-Market Road, Socorro, NM 87801, USA

${ }^{3}$ New Mexico Department of Game and Fish, P.O. Box 25112, Santa Fe, NM 87504, USA

${ }^{4}$ Oklahoma Biological Survey, Sutton Avian Research Center, and Department of Zoology, University of Oklahoma, Norman, OK 73019, USA

\begin{abstract}
The White-tailed Ptarmigan (Lagopus leucura) is the only ptarmigan species endemic to North America. In New Mexico, the species was first reported from the Sangre de Cristo Mountains in 1865 . At a latitude of slightly below $36^{\circ} \mathrm{N}$, this location is the extreme southern extent of White-tailed Ptarmigan distribution. Over the next 125 years, the species was reported in New Mexico only occasionally, usually by sheep herders or backpackers. By 1981, it was generally thought that White-tailed Ptarmigan had become extirpated from the state, and a reintroduction was attempted. Regardless of whether the remaining White-tailed Ptarmigan in New Mexico are a result of this reintroduction effort or are indigenous to the state, this remnant population might now be imperiled due to changes in the alpine vegetation and advancing timber lines resulting from climate change. Recent survey efforts have shown that White-tailed Ptarmigan exist in at least two areas in New Mexico, albeit separated by a considerable distance. Received 7 March 2011, accepted 6 June 2011.

Wolfe, D. H., L. C. Larsson, J. R. Oldenettel, H. A. Walker, and M. A. Patten. 2011. Status of populations of the White-tailed Ptarmigan at the southern edge of its range. Pages 247-258 in R. T. Watson, T. J. Cade, M. Fuller, G. Hunt, and E. Potapov (Eds.). Gyrfalcons and Ptarmigan in a Changing World, Volume I. The Peregrine Fund, Boise, Idaho, USA. http://dx.doi.org/ 10.4080/gpcw.2011.0122
\end{abstract}

Key words: climate change, Lagopus leucura, marginal population.

High ALTITUDE ECOSYSTEMS are sensitive to climate change and other anthropogenic disturbances such as livestock grazing (Pauli et al. 1996, Beniston 2003, Dirnböck et al. 2003, Walther et al. 2005). Advancement of timber- line and changes in species composition of alpine vegetation attributed to climate change have already affected various alpine obligate animals in North America and Eurasia. For example, by the end of the twentieth century, 
the American Pika (Ochotona princeps) had been extirpated from $28 \%$ of its range in western North America (Beever et al. 2003), and advancing timberlines have been associated with declines and increased isolation of populations of the Rock Ptarmigan (Lagopus muta) in France, Switzerland, and Japan (Revermann et al. 2007, Novoa et al. 2008, Bech et al. 2009, H. Nakamura, pers. comm.).

As a result of this burgeoning research on threats to high altitude ecosystems, both Wang et al. (2002) and Hoffman (2006) drew attention to possible deleterious effects of global climate change on the White-tailed Ptarmigan (L. leucura), the only ptarmigan species endemic to North America. As alpine habitat continues to be altered-and continues to shrink as timberlines creep upslope-some populations of the White-tailed Ptarmigan, particularly at the southern limits of the species' range, might be in jeopardy.

New Mexico hosts the southernmost population of the White-tailed Ptarmigan (Braun et al. 1993). Although this species was discovered in the region's high mountains in 1865 (Coues 1875), decades before New Mexico statehood, little is known of the species' distribution and abundance in the state. Indeed, after a lengthy period with no reported sightings, it was posited that the species was extirpated from New Mexico (Hubbard 1978), a supposition that led, in 1981, to the transplanting of 43 ptarmigan from Colorado into the Truchas Peaks area of the Sangre de Cristo Mountains. Yet Hoffman's (2006) statement that birds were released into "suitable habitat outside of natural range" is erroneous because the species was long known from the Sangre de Cristo Mountains (Coues 1875), including Truchas Peaks specifically (Bailey 1928). Additionally, sightings as late as 1974 in the vicinity of the releases as well as sightings from several other locales in New Mexico through at least 1979 belie the notion that the species was being introduced into the state in 1981.
Various misunderstandings and the general dearth of information aside, no formal survey of the species has previously been attempted in New Mexico. From 2006 through 2010, we surveyed for the White-tailed Ptarmigan in alpine areas of north-central New Mexico to fill gaps in our knowledge of the species' current distribution and abundance. In this paper we detail results of those surveys, compile historical records, and add a compendium of all recent sightings. We map sites of occurrence and highlight other alpine sites with suitable habitat to present as thorough as possible an assessment of the White-tailed Ptarmigan's status and distribution in New Mexico given the still limited information.

\section{Methods}

Our paper mimics Martin et al.'s (2004) detailed review of the status and distribution of L. l. saxatilis, the White-tailed Ptarmigan subspecies endemic to Vancouver Island, British Columbia. In our case, Oldenettel (http://sites. google.com/site/oldenettelspage/Home/yyyy) summarized ptarmigan records for New Mexico for a number of years, during which he collected fortuitously from numerous contacts in New Mexico birding and research circles. To these data, we added records from our surveys in the summers of 2006-2010, as well as data from other sources (e.g., a search of the ORNIS on-line database, http://ornisnet.org). We began limited surveys in areas where presence of the species seemed likely or had been reported recently. From 2006 through 2010, we searched $\sim 25 \mathrm{~km}^{2}$ of alpine habitat in the Latir Peak, Pecos, and Wheeler Peak wilderness areas and $\sim 2 \mathrm{~km}^{2}$ of alpine habitat on nearby peaks. In addition to searching for birds, we also searched for and collected all ptarmigan feces and feathers. From 2006 through 2010, approximately 900 person hours were spent surveying. In 2010, we also deployed temperature/humidity data loggers. We placed these loggers in paired sets, with one on the surface, and a second nearby in a rift trench or crevice between boulders that we deemed may be a suitable 
thermal refugium. We derived New Mexico White-tailed Ptarmigan density ranges based on Colorado ptarmigan surveys where estimates range from 2.0 to $13.5 \mathrm{birds} / \mathrm{km}^{2}$ (Braun et al. 1993).

\section{Results}

The White-tailed Ptarmigan was reported in New Mexico only sparingly before the 1970s (Figure 1), but early records include three extant specimens from 1904-1906 (USNM 193236, 194588, and 194589) and another from 1924 (MSB 891). The sharp uptick in records in recent decades most likely reflects an increase in observer awareness and reporting rather than an increase in the species' population size.

The species currently is known from two core areas in New Mexico (Figure 2), the first being along the Santa Barbara Divide in the Pecos Wilderness Area, the second in the Wheeler Peak Wilderness Area. Alpine portions of these wilderness areas are separated by $\sim 50 \mathrm{~km}$. Historical records include those from three additional areas of alpine habitat, all located north of the two aforementioned areas of alpine habitat.

Demographic data are almost non-existent, but there are several indications of successful reproduction. For example, a recently hatched nest was found in 1993 on Barbara Peak, 5 $\mathrm{km}$ east of the 1981 release site (Wolfe 2006) and, in the same area, Oldenettel observed a brood in 1996, as well as a single chick with a pair of adults in 2005. In the Wheeler Peak Wilderness Area, $\sim 50 \mathrm{~km}$ from the 1981 release site, broods were observed in 1979 and 2007 (Wolfe and Patten 2009). In 2010, we found nest remains on South Jicarita Peak, but we could not determine the nest's outcome because of the poor condition of remaining eggshell fragments.

Pecos Wilderness Area.-On the basis of US Geological Survey topographic maps and prior knowledge of the Pecos Wilderness Area, we surveyed thoroughly at least $70 \%$, and perhaps as much as $80 \%$, of potentially suitable ptarmigan habitat in the wilderness area. The only locations where ptarmigan were observed were on the ridge between Jicarita and Trouble peaks. We found birds - as well as their feces and feathers - in the vicinity in all 5 years of our effort. In addition, Bosler (2007) photographed a cock and hen on Jicarita Ridge on 28 July 2007; one published photograph was of a bird with almost completely white plumage, certainly a different individual than any we had seen that year. We found feathers on Barbara Peak in 2007 and 2010 and feces on Trouble Peak in 2008, 2009, and 2010.

We surveyed ridges between Barbara Peak and Chimayosos Peak, but found neither ptarmigan nor their sign except for 2 fecal piles on an unnamed peak just east of Chimayosos Peak, but, in 2008, we discovered ptarmigan feathers on Chimayosos Peak. There had been no records for Chimayosos Peak since a 1992 sighting of 10 individuals (P. Hendricks, in litt.). We failed to find ptarmigan on the summit of North Truchas Peak and on the eastern slopes of the other Truchas peaks and, thus, we surmise that it is unlikely ptarmigan occupy any of the Truchas peaks. We conclude that the White-tailed Ptarmigan occupies the area from Barbara Peak (southwest) to Jicarita Peak (northeast), but occasionally ventures as far west as Chimayosos Peak. We estimate that $10-15 \mathrm{~km}^{2}$ are occupied in the Pecos Wilderness Area with a population numbering between 50 and 100 individuals with a range of 20-203 based on Colorado densities (Braun et al. 1993).

Wheeler Peak Wilderness Area.-On the basis of USGS topographic maps and our familiarity of the area and of ptarmigan occupancy, we crudely estimate that the Wheeler Peak population could number fewer than 50. Approximately $3-6 \mathrm{~km}^{2}$ is occupied range giving a population size range of 6-81 ptarmigan in the Wheeler Peak Wilderness Area. All birds detected in the Wheeler Peak Wilderness Area 
Figure 1. Reporting history of White-tailed Ptarmigan (Lagopus leucura) in New Mexico.

Figure 2. Distribution of White-tailed Ptarmigan sightings or sign in New Mexico, 2006-2010.
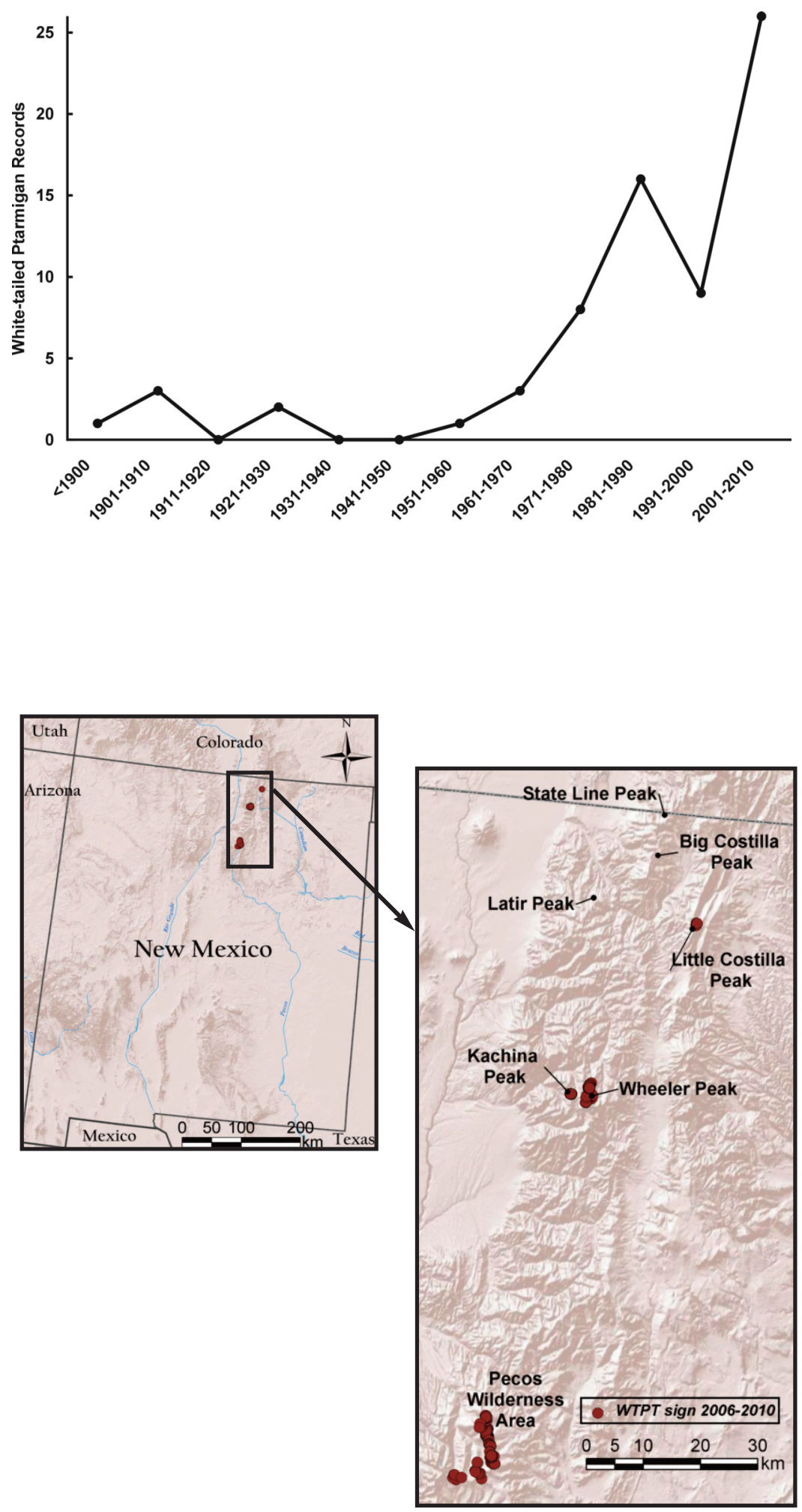
were at elevations between $3780 \mathrm{~m}(12,400 \mathrm{ft}$.) and $3860 \mathrm{~m}(12,660 \mathrm{ft}$.), although sign (feathers or feces) was found as high as $4000 \mathrm{~m}$ $(13,100 \mathrm{ft}$.$) .$

Despite suitable habitat surrounding trails to Wheeler Peak, we did not locate any ptarmigan nor find any of their feces or feathers in proximity to these trails. Several groups of hikers traverse these trails daily en route to Wheeler Peak, the highest peak in New Mexico. Hikers are not the sole disturbance on and near trails. Many hikers are accompanied by unleashed dogs that range 100-200 m from the trail, and some dogs doubtless range farther. During our 2008 survey, one dog befriended many hikers, including us, but did not seem to belong to anyone. These dogs could represent a constant threat of predation to ptarmigan and could result in ptarmigan avoiding suitable habitat $<500 \mathrm{~m}$ from heavily traveled trails. Away from these trails, which receive heavy foot traffic, we posit that ptarmigan might be fairly abundant.

Additional alpine habitat adjacent to the Wheeler Peak Wilderness Area occurs on land that belongs to the sovereign nation of Pueblo de Taos and access is restricted. Other alpine habitat can be found north of Wheeler Peak Wilderness Area, including Frazer Mountain, Kachina Peak, and Gold Hill. We surveyed Frazer Mountain and Kachina Peak in 2010; we located ptarmigan on Kachina Peak, but found no sign on Frazer Mountain. We have received unsubstantiated reports of ptarmigan from Gold Hill, so future plans include extensive surveys of that area.

Latir Peaks Wilderness Area.-Historical White-tailed Ptarmigan records exist from the Latir Peaks Wilderness Area. In 2009, we surveyed approximately $30 \%$ of the alpine habitat in the area and found no sign of ptarmigan. There appears to be a paucity of large boulder fields and willow stands, both of which seem to correlate with ptarmigan presence. We conclude that, although the Latir Peaks Wilderness
Area might support a small ptarmigan population, it more likely is visited only periodically by dispersers.

\section{Discussion}

Whereas ptarmigan are known currently from only the Pecos and Wheeler Peak wilderness areas, which are separated by $\sim 50 \mathrm{~km}$, there might yet remain remnant populations in other alpine areas. Aside from the areas that we have not yet surveyed, we estimate that the number of ptarmigan within the two wilderness areas ranges from 100 to 150 individuals. If the species occurs on areas we have yet to survey (see below), an estimated census of the Whitetailed Ptarmigan for the whole of New Mexico might be closer to 200-300 individuals.

Historical White-tailed Ptarmigan records also exist from State Line Peak and Big Costilla Peak (Figure 2), although these locations support less suitable habitat than do the known occupied areas. In 2010, we received a report from a hiker of a ptarmigan sighting on Little Costilla Peak, and investigated that area in August 2010. As with the Latir Peaks Wilderness Area, there was a paucity of both boulder fields and willows. After several person-hours of searching, we did find a few old fecal piles, likely from the previous winter or older. We doubt that Little Costilla Peak supports a yearround population, but it might be a stopover site for dispersers. The Wheeler Peak Wilderness Area is the closest known occupied site to the unsurveyed areas. Latir Peaks Wilderness Area is $\sim 25 \mathrm{~km}$ north of and Big Costilla Peak is $\sim 30 \mathrm{~km}$ northeast of Wheeler Peak Wilderness Area. State Line Peak lies 25 km northeast of Latir Peaks and $\sim 15 \mathrm{~km}$ north of Big Costilla Peak. The distance of State Line Peak to the nearest suitable alpine habitat in Colorado is only $\sim 5 \mathrm{~km}$.

In Colorado, Giesen and Braun (1993) and Hoffman and Braun (1975) documented ptarmigan maximum dispersal distances of 29 $\mathrm{km}$ and $23 \mathrm{~km}$, respectively, but these long-dis- 
Figure 3.

Distribution of

White-tailed

Ptarmigan

sightings or sign by elevation in the Sangre de Cristo Mountains, New Mexico, 20072010.

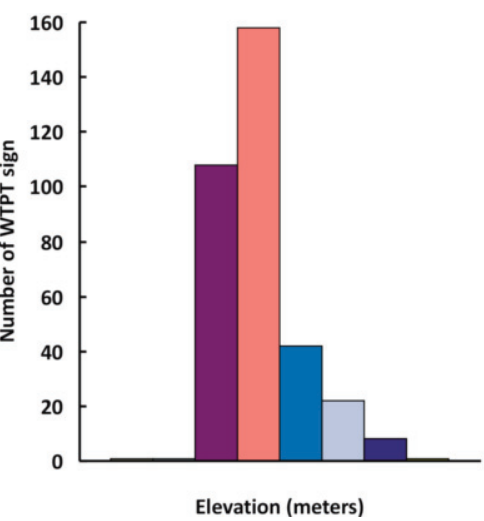

Figure 4. Average daily temperatures for the month of August, 2010 in the Pecos Wilderness Area, New Mexico.

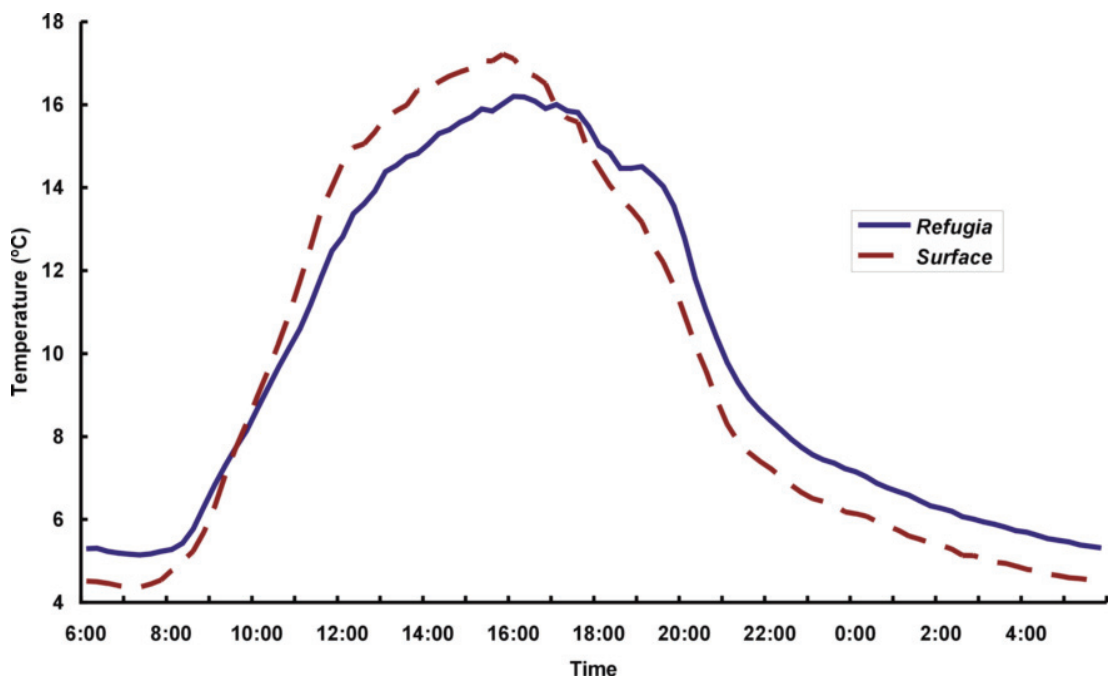

Figure 5. Average daily temperatures for the month of August, 2010 in the Wheeler Peak Wilderness Area, New Mexico.

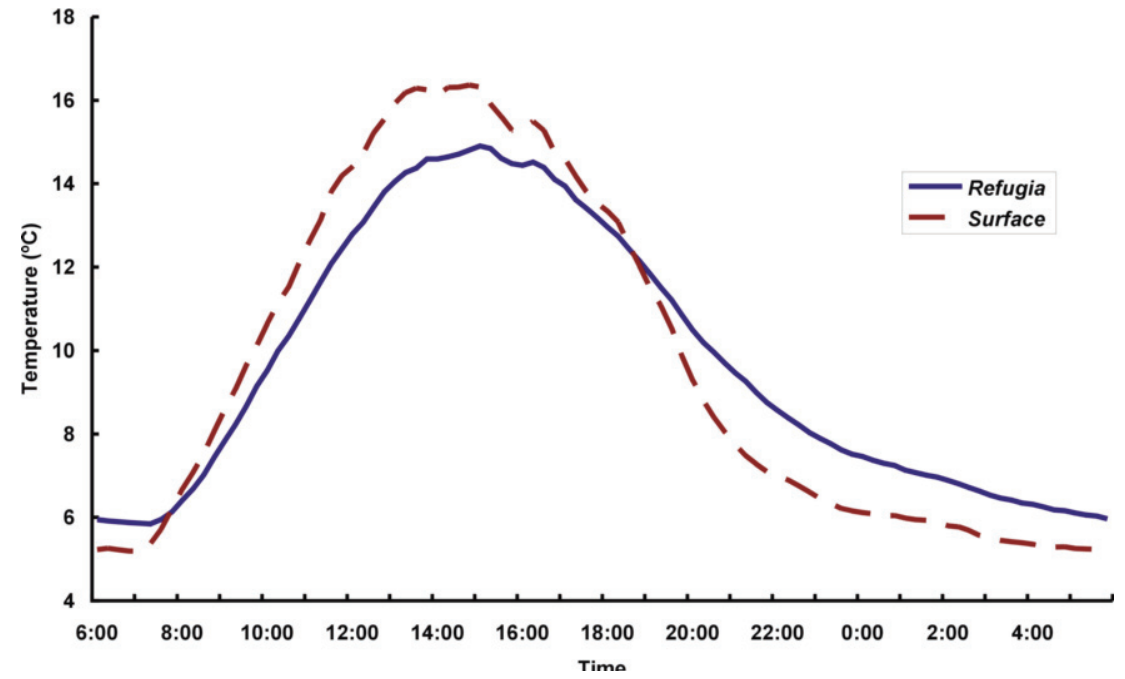


tance dispersals were in areas where suitable alpine habitat occurred among larger populated areas, even if some were in the form of small, stepping-stone patches of alpine habitat. Because alpine habitat is generally lacking between the Pecos and Wheeler Peak wilderness areas, we surmise that there is likely to be little movement between them. Dispersal between Wheeler Peak Wilderness Area and alpine habitats farther north in New Mexico might be more plausible, although single movements $25 \mathrm{~km}$ or greater would be required among patches of suitable habitat.

The amount of intact high alpine habitat is likely the primary factor limiting White-tailed Ptarmigan distribution in New Mexico: $>99 \%$ of ptarmigan sightings or sign were at elevations $>3750 \mathrm{~m}(12,300 \mathrm{ft}$.), and $67 \%$ were $>3800 \mathrm{~m}(12,470 \mathrm{ft}$.; Figure 3). Even within alpine above $3750 \mathrm{~m}$, we surmise that the proximity of large boulder fields, rifts, and large willow stands (either on ridges or slightly downslope) are essential for ptarmigan persistence. Willows likely provide food, protection from predators, and thermal refugia. Indeed, the refugia temperatures were both lower during the day and warmer at night than were surface temperatures (Figures 4-5).

Much of the remaining "alpine" habitat within both the Pecos Wilderness Area and Wheeler Peak Wilderness Area seems to be transforming into lush grassy pasture with, at least in some locations, a paucity of sedges and forbs. We recommend further investigations on ptarmigan diet, microclimate, and vegetation composition on the alpine ridges to determine if conditions are suitable to support a viable population of the White-tailed Ptarmigan. Moreover, populations in some areas with suitable habitat (e.g., Wheeler Peak Wilderness Area) might be limited by the presence of unleashed dogs that frequently accompany day hikers. If maintaining a viable ptarmigan population in this wilderness area is a priority, it might be necessary to enact and enforce a leash law.

We also recommend that genetic analyses be conducted - using material from molted feathers or blood from captured birds - to compare population structure and detect potential inbreeding depression in New Mexico relative to core populations in southern Colorado. Lastly, we recommend routine photographic points at different elevations to monitor advancing timberlines associated with global climate change. To this end, photo points we established in 2007 and 2008 should be repeated at least every five years and additional photo points established. As timberline creeps upslope, alpine habitat shrinks, and as alpine habitat shrinks, the ptarmigan population either will have to become denser (i.e., smaller home ranges) or will risk falling to levels below a threshold of viability.

\section{ACKNOWLEDGMENTS}

Funding was provided by the Oklahoma Biological Survey and a Federal Aid in Wildlife and Sport Fish Restoration Grant administered by the New Mexico Department of Game and Fish. 
Appendix. Records sorted by date of White-tailed Ptarmigan (Lagopus leucura) sightings and collections in New Mexico.

\begin{tabular}{|c|c|c|c|}
\hline Date & County; Location & Number & Data Source ${ }^{a}$ \\
\hline \multicolumn{4}{|c|}{ A. EARLY RECORDS (1860s-1949) } \\
\hline$? 1865$ & $?$ & $?$ & Coues (1875) \\
\hline ? 1892 & Taos; Mora Pass & $?$ & Bailey (1904) \\
\hline 24 Jan 1904 & Taos; above Twining & "flock" & $\begin{array}{l}\text { Bailey (1904); one specimen taken } \\
\text { (USNM 193236) }\end{array}$ \\
\hline 24 Jul 1904 & Taos; Wheeler Peak (?) & 1 & Bailey (1905); specimen (USNM 194589) \\
\hline 06 Aug 1904 & Taos; Wheeler Peak (?) & 1 & Bailey (1905); specimen (USNM 194588) \\
\hline Jul-Aug 1904 & Taos & 2 & Bailey $(1905)$ \\
\hline 20 Aug 1904 & Taos; Costilla Peak & sign & Bailey (1905) \\
\hline 19 Jun 1924 & Colfax; 20 mi NE of Taos; Wheeler Pe & eak & specimen (MSB 891) \\
\hline Nov 1926 & Taos; Costilla Peak & 2 & J. S. Ligon* \\
\hline \multicolumn{4}{|c|}{ B. RECENT RECORDS (1950-1999) } \\
\hline Jul 1952 & Taos; Costilla Peak; Ricardo Creek & 5 & J. Brewer * \\
\hline Dec 1966 & Santa Fe; Santa Fe Baldy & $?$ & $?^{*}$ \\
\hline Apr 1969 & Taos; Latir Peak & 3 & D. Saylors * \\
\hline Feb 1970 & Taos; Costilla Peak & 2 & R. Welsh * \\
\hline Nov 1974 & Rio Arriba; Cumbres Pass & 3 & J. Lesparance * \\
\hline Sep 1976 & Taos; Wheeler Peak & 5 & J. Crellin * \\
\hline Nov 1976 & Santa Fe; Santa Fe Baldy & 2 & F. Stimson * \\
\hline Jul 1977 & Taos; Gold Hill & $?$ & B. Morris * \\
\hline Aug 1978 & Taos; Latir Peak & 2 & J. Hubbard * \\
\hline Aug 1979 & Taos; Latir Peak & $?$ & A. Renfro * \\
\hline Aug 1979 & Taos; Wheeler Peak & $2+$ brood & A. Renfro * \\
\hline Aug 1979 & Taos; State Line Peak & 2 & R. Peterson * \\
\hline May 1981 & Rio Arriba/Mora; Pecos W. Area & 22 (released) & J. Hubbard * \\
\hline Aug 1981 & Taos; North Fork Lake & 1 & W. Baltosser * \\
\hline Sep 1981 & Rio Arriba/Mora; Pecos W. Area & 21 (released) & W. Baltosser * \\
\hline Jun 1982 & Taos; State Line Peak & 1 & E. Espanoza * \\
\hline Aug 1982 & Taos; El Vintrero & 7 & R. Peterson * \\
\hline Sep 1983 & Mora; Middle Fork Lake & 20 & D. De Lorenzo * \\
\hline Sep 1983 & Mora; Rincon Bonito & $?$ & D. De Lorenzo * \\
\hline Jul 1985 & Rio Arriba; Truchas Peak & 10 & M. Frenzel * \\
\hline Aug 1985 & Mora; Rincon Bonito & 5 & A. Sandoval * \\
\hline Aug 1985 & Rio Arriba; Truchas Peak & 10 & A. Sandoval * \\
\hline Aug 1985 & Taos; Jicarita Peak & 4 & A. Sandoval * \\
\hline Aug 1986 & Santa Fe; Santa Fe Baldy & 1 & E. Johnson * \\
\hline Oct 1986 & Mora; Rincon Bonito & 12 & T. Stevenson * \\
\hline Aug 1987 & Mora; Pecos Baldy & $1+4$ chicks & C. MacCarter * \\
\hline Aug 1990 & Santa Fe; Santa Fe Baldy & 4 & C. Crawford * \\
\hline 1 Sep 1992 & Rio Arriba/Mora; Chimayosos Peak & 10 & P. Hendricks in litt. \\
\hline 11 Aug 1993 & Rio Arriba; Barbara Peak & nest & Wolfe (2006) \\
\hline Aug 1996 & Taos; Barbara Ridge & $6+3$ chicks & J. Oldenettel * \\
\hline Sep 1998 & Taos; Jicarita Peak & $?$ & B. West * \\
\hline Jul 1999 & Mora; Pecos Baldy & 1 & E. Rominger * \\
\hline Sep 1999 & Taos; Wheeler Peak & 6 & E. Rominger * \\
\hline
\end{tabular}




\section{MODERN RECORDS (2000-PRESENT)}

May 2000

Jul 2000

Sep 2000

Jun 2002

Aug 2002

Aug 2002

Aug 2002

17 Aug 2002

Sep 2002

Jul 2004

Jul 2004

Aug 2004

Aug 2005

Jun (?) 2006

Jun (?) 2006

19 Jul 2006

19 Jul 2006

11 Jul 2007

12 Jul 2007

28 Jul 2007

28 Aug 2007

23 Jul 2008

5-6 Aug 2008

8 Aug 2008

10 Aug 2008

16 Aug 2008

25 Jun 2009

26 Jun 2009

1 Aug 2009

22 May 2010

23 May 2010

Jul 2010

Jul 2010

7 Jul 2010

8-10 Jul 2010

19 Aug 2010

15 Sep 2010

17 Sep 2010

19 Sep 2010
Taos; Kachina Peak

Taos; Jicarita Peak

Taos; Mount Walter

Taos; Latir Peak

Taos; Jicarita Peak

Taos; Jicarita Peak

Rio Arriba; Truchas Peak

Santa Fe; Santa Fe Baldy

Taos; Wheeler Peak

Taos; Jicarita Peak

Taos; Jicarita Peak

Taos; Jicarita Peak

Taos; Barbara Ridge

Taos/Rio Arriba; Jicarita Peak/Ridge

Rio Arriba/Mora; above Rio Santa Barbara 2

Rio Arriba; Trouble Peak; Jicarita Ridge

Rio Arriba; Jicarita Ridge

Rio Arriba; Jicarita Ridge

Rio Arriba, Barbara Peak

Taos; Santa Barbara Ridge

Taos; Mount Walter

Taos; Horseshoe Lake

Rio Arriba/Mora; Chimayosos Peak

Rio Arriba; Jicarita Ridge

Taos; Mount Walter

Taos; Wheeler Peak

Taos; Jicarita Ridge

Taos; Jicarita Peak

Taos; Mount Walter

Taos; Jicarita Peak

Taos; Jicarita Peak

Taos/Colfax; Little Costilla Peak

Taos; Gold Hill

Taos; Mount Walter

Taos; Wheeler Peak

Taos; Kachina Peak

Taos; Mount Walter

Taos; Jicarita Peak

Taos; ridge north from Jicarita Peak
5 E. Rominger *

6 ? *

3 L. Ahlm *

5 E. Rominger *

5 R. Gardner *

2 E. Rominger *

1 E. Rominger *

feather J. Klingel*; specimen (MSB 23301)

11 E. Rominger *

1 C. Black *

3 J. Beason *

2 S. O. Williams *

2+chick J.Parmeter *

4 C. E. Braun \#

2 C. E. Braun \#

feathers D. H. Wolfe, specimens (MSB 2551825521)

$3 \quad$ Wolfe (2006); photographs

2 Wolfe and Patten (2009); photographs, feather specimens

feathers Wolfe and Patten (2009); specimens

2 Bosler (2007); photographs

$6+2$ chicks Wolfe and Patten (2009); photographs

$1 \quad$ E. Rominger in litt.

feathers Wolfe and Patten (2009); specimens

$3 \quad$ Wolfe and Patten (2009); photographs

$3 \quad$ Wolfe and Patten (2009); photographs

4-6 E. Rominger in litt.

$1 \quad$ Wolfe and Patten (2010); photographs

$3 \quad$ Wolfe and Patten (2010); photographs

$3 \quad$ Wolfe and Patten (2010); photographs

$2 \quad$ Wolfe et al. (2010); photographs

$1 \quad$ Wolfe et al. (2010); photographs

4 Hassell (Pers. Comm.)

? Malixi (Pers. Comm.)

$1 \quad$ Wolfe et al. (2010)

feathers Wolfe et al. (2010); specimens

$1 \quad$ Wolfe et al. (2010); photographs

$3 \quad$ Wolfe et al. (2010); photographs

nest Wolfe et al. (2010); specimens

feathers
Wolfe et al. (2010); specimens

a Museum abbreviations: MSB = Museum of Southwestern Biology, University of New Mexico, Albuquerque;

USNM = National Museum of Natural History, Smithsonian Institution, Washington, DC.

* Records compiled by J. R. Oldenettel (http://sites.google.com/ site/oldenettelspage/Home/yyyy), data from several sources, primarily the New Mexico Ornithological Society Field Notes. Some location names are likely the nearest known landmark. It is also likely that several location name discrepancies exist, and also possible that some records are of misidentified birds.

\# USDA Forest Service. 2007. Management indicator species assessment - Carson National Forest. USDA Forest Service - Southwestern Region. Unpublished report.

http://www.fs.fed.us/r3/carson/plans/mis\%20assessment/2007_mis_assessment.shtml 


\section{Literature Cited}

BAILEY, F. M. 1904. Additional notes on the birds of the Upper Pecos. Auk 21:349-363.

BAILEY, F. M. 1905. Notes from northern New Mexico. Auk 22:316-318.

BAILEY, F. M. 1928. The Birds of New Mexico. New Mexico Department of Game and Fish, Santa Fe, New Mexico, USA.

Bech, N., J. BoIsSier, S. Drovetski, AND C. NovoA. 2009. Population genetic structure of Rock Ptarmigan in the "sky islands" of French Pyrenees: Implications for conservation. Animal Conservation 12:138-146.

BeEver, E. A., P. F. Brussard, AND J. Berger. 2003. Patterns of apparent extirpation among isolated populations of Pikas (Ochotona princeps) in the Great Basin. Journal of Mammalogy 84:37-54.

Beniston, M. 2003. Climatic change in mountain regions: A review of possible impacts. Climatic Change 59:5-31.

Bosler, D. 2007. The ptarmigan trek. [Louisiana State University Museum of Natural Science] Museum Quarterly 25(3):12-13.

Braun, C. E, K. Martin, and L. A. Robb. 1993. White-tailed Ptarmigan (Lagopus leucurus). In A. Poole and F. Gill (Eds.). The Birds of North America, no. 68. The Birds of North America, Inc., Philadelphia, Pennsylvania, USA.

CouEs, E. 1875. On the breeding-habits, nest, and eggs, of the White-tailed Ptarmigan (Lagopus leucurus). Bulletin of the United States Geological and Geographical Survey of the Territories ( $2^{\text {nd }}$ series) 5:263-266.

Dirnböck, T., S. Dullinger, AND G. GRABHERR. 2003. A regional impact assessment of climate and land-use change on alpine vegetation. Journal of Biogeography 30:401-417.

GiEsen, K. M., AND C. E. Braun. 1993. Natal dispersal and recruitment of juvenile White-tailed Ptarmigan in Colorado. Journal of Wildlife Management 57:72-77.

HoffMAn, R. W. 2006. White-tailed Ptarmigan (Lagopus leucura): A technical conserva- tion assessment. USDA Forest Service, Rocky Mountain Region.

Hoffman, R. W., and C. E. Braun. 1975. Migration of a wintering population of White-tailed Ptarmigan in Colorado. Journal of Wildlife Management 39:485-490.

HuBBARD, J. P. 1978. Revised check-list of the birds of New Mexico. New Mexico Ornithological Society Publication 6.

Martin, K., G. A. BRown, AND J. R. Young. 2004. The historic and current distribution of the Vancouver Island White-tailed Ptarmigan (Lagopus leucurus saxatilis). Journal of Field Ornithology 75:239-256.

Novoa, C., A. Besnard, J. F. Brenot, AND L. N. ELLISON. 2008. Effect of weather on the reproductive rate of Rock Ptarmigan Lagopus muta in the eastern Pyrenees. Ibis 150:270-278.

Pauli, H., M. GotTfried, AND G. Grabherr. 1996. Effects of climate change on mountain ecosystems - upward shifting of mountain plants. World Resources Review 8:382-390.

REVERMANN, R., N. ZBIndEN, H. SCHMID, AND B. SCHROEDER. 2007. Habitatmodelle fur das Alpenschneehuhn Lagopus muta helvetica in den Schweizer Alpen-Skaleneffekte und mogliche Auswirkungen des Klimawandels. Vogelwarte 45:276-277.

Walther, G.-R., S. Beißner, AND C. A. BURGA. 2005. Trends in the upward shift of alpine plants. Journal of Vegetation Science 16:541-548.

Wang, G., N. T. Hobbs, K. M. Giesen, H. GALBRAith, D. S. OJIMA, AND C. E. BRAUN. 2002. Relationships between climate and population dynamics of White-tailed Ptarmigan Lagopus leucurus in Rocky Mountain National Park, Colorado, USA. Climate Research 23:81-87.

Wolfe, D. H. 2006. Nesting documentation for the White-tailed Ptarmigan in the Sangre de Cristo Mountains, New Mexico. Publications of the Oklahoma Biological Survey 7:21-23.

Wolfe, D. H., AND M. A. PATten. 2009. 2008 Surveys for White-tailed Ptarmigan in the 
Sangre de Cristo Mountains, New Mexico. Unpublished report submitted to Oklahoma Biological Survey and New Mexico Department of Game and Fish. Sutton Avian Research Center, Bartlesville, Oklahoma, USA.

Wolfe, D. H., AND M. A. PATten. 2010. 2009 Surveys for White-tailed Ptarmigan in the Sangre de Cristo Mountains, New Mexico. Unpublished report submitted to Oklahoma Biological Survey and New Mexico Department of Game and Fish. Sutton Avian Research Center, Bartlesville, Oklahoma, USA.

Wolfe, D. H., M. A. Patten, And L. C. LarsSON. 2010. Status, distribution, and ecology of White-tailed Ptarmigan (Lagopus leucura) in the Sangre de Cristo Mountains, New Mexico. Final Report. Submitted to New Mexico Department of Game and Fish. Contract Number 10-516-000000018. Sutton Avian Research Center, Bartlesville, Oklahoma, USA. 
- Wolfe et Al. - 